\section{PSYCHOLOGICAL AND SOCIODEMOGRAPHIC CHARACTERISTICS AND DEVELOPMENT OF PHYSICAL EXERCISE DEPENDENCE}

\author{
CARACTERISTICAS PSICOLÓGICASESOCIODEMOGRÁFICAS EDESENVOLVIMENTO DE \\ DEPENDÊNCIADO EXERCÍCIO
}

CARACTERÍSTICAS PSICOLÓGICASY SOCIODEMOGRÁFICAS Y DESARROLLODE DEPENDENCIA DEL EJERCICIO

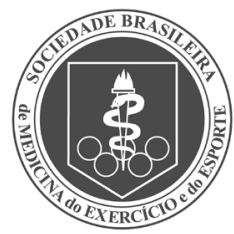

Original Article ARTIGo ORIGINAL Artículo Original
Almedina Numanović

(Psychologist)

Željko Mladenović (Psychologist)

Vladimir Janjić² (Doctor)

Branimir Radmanović ${ }^{2}$ (Doctor)

1. International University of Novi Pazar, Department for Pedagogical and Psychological Science, Novi

Pazar, Serbia.

2. University of Kragujevac, Faculty of Medical Sciences, Department of Psychiatry, Kragujevac, Serbia.

Correspondence:

Almedina Numanović, Vehba

Kolašinca 14, Novi Pazar,

Serbia, Europe.

almedinaasotic@yahoo.com

\begin{abstract}
Introduction: Excessive physical exercise combined with certain psychic and sociodemographic factors can lead to dependence. Objective:To examine which factors lead to the emergence of exercise dependence. Methods: Sample consisted of 103 men (mean age 27.3 years, SD 6.127) who performed exercises at gyms at least three times a week in the last year or more in Novi Pazar, Sjenica, Raska and Tutin, Serbia. Participants completed questionnaires and took appropriate tests. Results: Our results showed that there is no association between exercise dependence and financial status, number of siblings, level of education, family stability, health, and medication use among the interviewees. However, it was found that the degree of exercise dependence is associated with marital status and problems with the law. Regression analysis showed that body dysmorphia, body mass index and aggressiveness are better predictors of exercise dependence. Conclusion: People whose self-perception is dismorphic have lower self-esteem, and exercise in gyms to improve their physical appearance. If we consider other characteristics, such as unfavorable BMI, problems with the law and being single, it is hardly surprising these individuals cross the line between healthy exercise and exercise dependence. An important finding is that aggressiveness and exercise dependence are related to problems with the law due to aggression, and body dysmorphia. Level of Evidence; Diagnostic studies - Investigating a diagnostic test.
\end{abstract}

Keywords: Exercise; Self-esteem; Life; Aggression; Muscles; Body mass index.

\section{RESUMO}

Introdução: O exercício físico em excesso combinado com certos fatores psíquicos e sociodemográficos pode ocasionar dependência. Objetivo: Examinar quais fatores levam ao surgimento de dependência do exercício. Métodos: A amostra foi composta por 103 homens (média de idade 27,3 anos, DP6,127) que faziam exercicios em academia pelo menos três vezes por semana no último ano ou mais, em Novi Pazar, Sjenica, Raška e Tutin, na Sérvia. Os participantes responderam questionáriose fizeram testes apropriados. Resultados: Nossos resultados mostraram que não há associação entre dependência do exercício e situação financeira, número de irmãos, grau de escolaridade, estabilidade familiar, saúde e uso de medicação nos entrevistados. Contudo, verificou-se que grau de dependência do exercício é associado ao estado civil e a problemas com a lei. A análise de regressão mostrou que dismorfia corporal, índice de massa corporal e agressividade são preditores melhores de dependência de exercício. Conclusão: As pessoas cuja autopercepção éde dismorfia têm um nivel mais baixo de autoestima efazem exercícios na academia visando melhorar a aparência física. Se considerarmos outras características, tais como IMC desfavorável, problemas com a lei e ser solteiro, não éde estranhar que ultrapassem a linha entre o exercício saudável e a dependência do exercício. Um achado importanteéque a agressividade e a dependência do exercício estão relacionadas com problemas com a leidecorrentes de agressão edismorfia corporal. Nível de Evidência ll; Estudos diagnósticos - Investigação de um exame para diagnóstico.

Descritores: Exercício; Autoestima; Vida; Agressão; Músculos; Indice de massa corporal.

\section{RESUMEN}

Introducción: El ejercicio físico en exceso combinado con ciertos factores psíquicos y sociodemográficos puede ocasionar dependencia del ejercicio. Objetivo: Examinar qué factores llevan al surgimiento de dependencia del ejercicio. Métodos: La muestra fue compuesta por 103 hombres (media de edad 27,3 años, DE 6,127) que hacían ejercicios en gimnasios por lo menos tres veces por semana en el último año o más, en Novi Pazar, Sjenica, Raska y Tutin, en Serbia. Los participantes respondieron cuestionarios e hicieron pruebas apropiadas. Resultados: Nuestros resultados mostraron que no hay asociación entre dependencia del ejercicio y situación financiera, número de hermanos, grado de escolaridad, estabilidad familiar, salud y uso de medicación en los entrevistados. Sin embargo, se verificó que el grado de dependencia del ejercicio se asocia al estado civil y a los problemas con la ley. El análisis de regresión ha demostrado que el dismorfismo corporal, el índice de masa corporal y la agresividad son predictores mejores de dependencia de ejercicio. Conclusión: Las personas cuya auto percepción es de dismorfismo tienen un nivel más bajo de autoestima y hacen ejercicios en el gimnasio para mejorar la apariencia física. Si consideramos otras características, como el IMC desfavorable, problemas con la ley y ser soltero, no es sorprendente que sobrepasen la línea entre el ejercicio saludable y la dependencia del ejercicio. Un hallazgo importante es que la agresividad y la dependencia del ejercicio están relacionados con problemas con la ley derivadas de agresión y dismorfismo corporal. Nivel de Evidencia ll; Estudios de diagnósticos - Investigación de un examen para diagnóstico.

Descriptores: Ejercicio; Autoestima; Vida; Agresión; Músculos; Índice de masa corporal. 


\section{INTRODUCTION}

Exercise is a subgroup of a physical activity which is planned, structured and repeated with the aim of improving or keeping one or more components of body condition. Exercising shows significant advantages for physical and mental well-being of adults, children and teenagers. Bodybuilding as activity is between sport and entertainment. Main goal is to build up symmetrical physique which shows muscle size and their definition. Body image of body builder practitioners is researched because it's found that bodybuilder practitioners suffer from body image desecration and excessive exercises. The need for muscularity and displeasure of the muscle size is connected with tendency for health harmful practice, such as using of medicaments-drugs, obsessive training, dysfunctional nutrition, and reduced quality of lifeas a result of all specified.

Concept of too much exercising is first used to distinguish the useful aspects of usual training from drug or alcohol abuse or other auto-destructive behavior. Excessive training was considered as a positive addiction because of its beneficial effects on health, until it was discovered that, in many cases, excessive training is connected with increased sensitivity on injuries or dysfunction in social interactions. ${ }^{1}$

It's well-known that addictive behavior doesn't develop suddenly; instead, they go through a process which contains few phases. According to the theoretical model of habits and behavior, excessive training has the following components: representation, mood changes, tolerance, retirement, anxiety, conflict of addicted person with others, relapse. ${ }^{2}$

Second important aspect which should be considered is the difference between primary excessive training, when the exercise itself is the main aim and secondary form which is mainly consequence of eating disorder and has the purpose of easier weight control. While some authors claim that excessive exercise exists in absence of eating disorder, others point that training addiction is separate from eating disorder, although they share concerns about body and its performances. Studies about connection between excessive forms of exercises and eating disorders showed conflicting results. ${ }^{3}$

As regards to other forms of addictive behavior, excessive training also should be distinguished from obsessive-compulsive disorder. Respondents who exercise excessively are ego syntonic and they enjoy what they do, while obsessive-compulsive respondents are ego dystonic, they don't like their obsessions, although they feel compelled to perform them. ${ }^{4}$ Carter and associates found that the anxiety trait and obsessive-compulsiveness are related with higher commitment to exercise, and narcissism with higher physical activity. ${ }^{5}$

Exercise can become unsuitable if performed to extremes. Indicators of unsuitable exercising include exercising few times a day, or over longer time than recommended. There is also obsession with counting calories which are spent during training, outbursts of anger if the person is interrupted during exercising, cancellation or avoidance of social or professional responsibilities and organization of daily activities with respect to exercising.

It is important to distinguish excessive exercise, from gym enthusiastic exercisers behavior by symptoms of tolerance, retreat, lack of control, nonchalance, decrease in other activities and perseverance visible in dependent individuals. ${ }^{6}$ Studies show that male gym users show greater anxiety about their body compared to those who don't use gym. One study showed that within men who use the gym concern for appearance and eating disordersare connected.

Bruno and associates research compared people with labile self-confidence and those with high narcissistic self-confidence in order to determine the role of these characteristics in the development of exercise dependence or as factors that can predict the risk of dependency. Psychologists and psychiatrists should carefully identify potentially excessive exercise in order to prevent potential risks, depending on the exercise. ${ }^{8}$
Aim of this work was to examine if there is a correlation between the degree of exercise dependence and self-confidence, self-respect, life satisfaction, aggressiveness, dysmorphia of the body of the bodybuilding practitioners personalities

\section{METHODS}

The sample in this study consisted of 103 bodybuilding practitioners from Novi Pazar, Sjenica, Tutin and Raska (Serbia, Europe). The sample included male weightlifters in gyms (age $M=27.3, S D=6.127$ years), and included practitioners who are between 18 and 45 years old, and who practiced in the gym at least three times a week an average in the past year or longer. The research was approved by the Committee for Research Ethics of the International University in Novi Pazar, on April 29, 2015, under the number 711/15-1. Participants volunteered after they were informed about the purpose of the study and didn't sign any Consent Form. There were no conflicts of interest.

The questionnaires, tests and scales used in the study are:

A questionnaire made by the authors for collecting data about physical and socio-demographic characteristics of the respondents. The questionnaire contained questions about respondent age, weight and height (for calculation of the Body Mass Index-BMI), the town in which he resides, the material status, marital status, the number of brothers and sisters, his education, whether he comes from a complete family, does he suffers from any chronic illness, or takes medication, whether there was someone suffering from a mental illness in his family, and whether he had problems with the law. In some questions, the respondent wrote his answer, while in others the answers were offered and the respondent marked the appropriate answer.

Exercise Dependence scale: can be used in a group or individually, and can only be used for people older than 18.It consists of 21 claims, where participants respond to what extent they agree with the given claim using a Likert scale. ${ }^{9}$

Muscle Dysmorphia Inventory (MDI 14) is designed to identify psychological and behavioral traits associated with muscle dysmorphia. MDI is consisted from five scales (Dietary Behavior, Body size-symmetry, Body building dependence, Physique protection and Supplement use). It consists of 27 items; a respondent expresses his level of agreement with each statement on a Likertscale. $^{10}$

The life satisfaction assessment scale which consists of 20 items. Seventeen items are related to the assessment of general well-being while three items are used for the situational assessment of satisfaction. The scale was created by combining five items from the life satisfaction scale (Satisfaction With Life Scale, Larsen et al.,1985), seven items of the overall satisfaction scale (Bezinović,1988), five items of the positive attitudes towards life scale (Positive Attitudes toward life, Grave, 1995), and three items from the life enjoyment scale. ${ }^{11}$

Self confidence-was tested by the questionnaire consisted of 14 items, which is very reliable (Cronbach's alpha=0.902) and has balanced factors. Items are evaluated by a participant on five-point Likert scale. ${ }^{12}$

Rosenberg Self-Esteem Scale: It is consisted of 10 items, five are defined in the positive direction and five are defined in the negative direction. Respondents rate each statement on a five- point scale expressing their level of agreement with each claim. ${ }^{13}$

Zuzul aggression questionnaire (1987). The questionnaire A-87 is designed for the evaluation of the aggressive behavior in provoking situations measuring thereby impulsive aggression. It is composed of 15 items, situations, and for each situation five possible reactions are offered. The sample of aggression provoking situations that are most commonly encountered in daily life is presented. ${ }^{14}$ The five answers offered for each situation represent one of the five modalities of the impulsive aggression: a) verbal manifested aggression b) physically manifested aggression, c) indirect or moved aggression d) verbal latent aggression, e) physical latent aggression. 


\section{RESULTS}

Statistical analysis was performed by using IBM SPSS Statistics for Windows, Version 19.0. (Armonk, NY, USA). Before we started the statistical analysis, we assured that all the requirements for applying the procedures whose results are shown here are met. The data originate from the appropriate level of measurement, they were normally distributed and variances were homogeneous.

We used One-way ANOVA to examine if there are significant differences in respondents' exercise dependence across the levels of the variables (questions) that relate to their socio demographic characteristics. In other words, the respondents' score on a scale measuring the exercise dependence was used as a dependent variable, and the respondents'answers to questions from the questionnaire relating to socio-demographic characteristics were used as an independent variable. In this way, we examined whether some participants'socio-demographic characteristics influence on exercise dependence development. The ANOVA results showed that there is no statistical difference in exercise dependence between participants of different material status, number of brothers and sisters, education and whether they come from a complete family or not. Also there were no differences in exercise dependence found between healthy and those who have a chronic illness, or between those who take and do not take medication. It is important to note that none of the respondents in our sample confirmed the existence of the heredity of mental illness in their family, so this variable was omitted from the analysis.

The significant difference in exercise dependence was found between the participants of different marital status, $p<.01(F(1,101)=9.88, p=$ 0.002), descriptive statistics is shown in the Table 1.

Another significant difference in exercise dependence was found between participants who had problems with the law and those that didn't, $p<.05(F(1,101)=5.01, p=0.027)$, descriptive statistics is shown in the Table 2.

In Table 3 we have shown the inter-correlations of all psychological variables that had been examined in this study including exercise dependence and Body Mass Index.

Table1. Participants' exercise dependence score descriptive statistics across the levels of the independent variable marital status.

\begin{tabular}{c|c|c|c|c}
\hline & N & Mean & Std. Deviation & Std. Error \\
\hline Married & 21 & 56.05 & 26.24 & 5.73 \\
\hline Unmarried & 82 & 73.54 & 21.79 & 2.41 \\
\hline Total & 103 & 69.97 & 23.71 & 2.34 \\
\hline
\end{tabular}

Table 2. Participants' exercise dependence score descriptive statistics across the levels of the independent variable "problems with the law".

\begin{tabular}{c|c|c|c|c}
\hline & N & Mean & Std. Deviation & Std. Error \\
\hline Problems with the law & 13 & 83.46 & 19.62 & 5.44 \\
\hline No Problems with the law & 90 & 68.02 & 23.71 & 2.49 \\
\hline Total & 103 & 69.97 & 23.71 & 2.33 \\
\hline
\end{tabular}

Table 3. Inter correlations of respondents' psychological characteristics including exercise dependence and Body Mass Index (BMI).

\begin{tabular}{c|c|c|c|c|c|c|c}
\hline Variable & $\begin{array}{c}\text { Self- } \\
\text { conf. }\end{array}$ & $\begin{array}{c}\text { Self- } \\
\text { estm. }\end{array}$ & $\begin{array}{c}\text { Life } \\
\text { satisf. }\end{array}$ & Aggressiv. & $\begin{array}{c}\text { Body } \\
\text { dysmorfia }\end{array}$ & BMI & $\begin{array}{c}\text { Exercise } \\
\text { depend. }\end{array}$ \\
\hline Self-confidence & 1 & .098 & .186 & .003 & -.048 & -.151 & -.026 \\
\hline Self-esteem & .098 & 1 & $.212^{*}$ & $-.273^{* *}$ & $-.408^{* *}$ & .175 & $-.260^{* *}$ \\
\hline Life satisfaction & .186 & $.212^{*}$ & 1 & .061 & $.249^{*}$ & -.075 & $.222^{*}$ \\
\hline Aggressiveness & .003 & $-.273^{* *}$ & .061 & 1 & $.675^{* *}$ & -.103 & -.598 \\
\hline Body dysmorphia & -.048 & $-.408^{* *}$ & $.249^{*}$ & $.675^{* *}$ & 1 & -.119 & $.724^{* *}$ \\
\hline BMl & -.151 & .175 & -.075 & -.103 & -.119 & 1 & $-.272^{* *}$ \\
\hline Exercise depend. & -.026 & $-.260^{* *}$ & $.222^{*}$ & -.598 & $.724^{* *}$ & $-.272^{* *}$ & 1 \\
\hline * Correlation is significant at the 0.05 level (2-tailed). ${ }^{* *}$ Correlation is significant at the 0.01 level (2-tailed).
\end{tabular}

\section{DISCUSION}

Our results showed that there is no connection between exercise dependence and participants' material status, number of brothers and sisters, education and completeness of their family. There were no connections found neither between exercise dependence and participants health nor between exercise dependence and taking of the medication. None of the respondents confirmed the existence of the heredity of mental illness in their family, so this variable was omitted from the analysis.

Marital status and the degree of exercise dependence are connected because there is a statistically significant difference in exercise dependence between participants of different marital status. The lower level of exercise dependence is shown in the participants who are married in comparison with those who are unmarried (in relationship or single) (Table 1). A possible explanation is that unmarried participants have more free time and exercise in the gym, while married people do not have so much free time, they work to support their families, and on the other hand it is understandable that unmarried people want to improve their physical appearance to attract persons of the opposite sex.

Exercise dependence and problems with the law are connected, people who had or have any problems with the law manifested statistically significant higher degree of exercise dependence in comparison to those who had no problems with the law (Table 2). People whose aggression is expressed have problems with the law, people who are aggressive are in need to increase muscle mass, they would like to look more dangerous, so they could indulge in fights etc., and they turn to bodybuilding weight training developing exercise dependence consequently. ${ }^{15}$

Self-esteem is correlated with life satisfaction (Table 3), if a degree of life satisfaction is higher, the degree self-esteem will be higher. Self-esteem is negatively correlated with body dysmorphia. People who see own bodies as dysmorphic are insecure and dissatisfied with themselves and have less confidence. ${ }^{16-20}$ Aggressiveness is positively correlated with body dysmorphia, correlation is large and significant. People who see their own body as dysmorphic often display aggressiveness probably due to above-mentioned insecurity and a low self-respect. Correlation between self-respect and aggressiveness is low, negative and significant. Self-confident people do not manifest aggression; there are probably some psychological reasons. Manifestation of aggressiveness would compromise the good image one wants others to have of him, so aggressive behavior is avoided.

The highest significant positive correlation we see in Table 3 is between exercise dependence and body dysmorphia. Regarding the correlation between exercise dependence and aggressiveness, the results show that the correlation is high, positive and is statistically significant. Correlation between exercise dependence and Body Mass Index is medium, negative and statistically significant. In other words, if BMl is greater than the exercise dependence is smaller and vice versa. This is a very interesting finding. A high BMI can be used as an indicator of high body fatness so those respondents who are fit express lesser degree of the exercise dependence. A lower, significant, but negative correlation is found between exercise dependence and self-esteem.

We decided to deepen the explanations we just provided, so we conducted a regression analysis by taking the exercise dependence as a dependent variable, and other psychological characteristics and BMI as predictors. So, we decided to check which of the displayed properties could be used to trace the development of exercise dependence. According to the correlations shown in Table 3, it appears that there are many candidates for the predictors for development of the exercise dependence. However regression analysis according to stepwise method whose results are shown in Table 4 and 5 showed that only three models can be distinguished. As we see, the highest percentage of exercise dependence variance can be explained by body dysmorphia (around 50\%), a bit more if the BMI is included in the model, and the 
most if the model includes aggression, other variables do not contribute significantly to the quality of the prediction. Results from Table 6 show that perceiving your body as a dysmorphic is most likely to lead to the development of exercise dependence, in addition if BMl is less favorable and aggression is higher, the development of exercise dependence will be more pronounced.

Table 4. Model summery of the regression analysis with exercise dependence score as a dependent variable and examined psychological characteristics including Body Mass Index (BMI).

\begin{tabular}{c|c|c|c|c}
\hline Model & R & R Square & Adjusted R Square & Std. Error of the Estimate \\
\hline 1 & $.724^{\mathrm{a}}$ & .524 & .519 & 16.43884 \\
\hline 2 & $.748^{\mathrm{b}}$ & .559 & .550 & 15.90044 \\
\hline 3 & $.761^{\mathrm{c}}$ & .580 & .567 & 15.60543 \\
\hline
\end{tabular}

Predictors: (Constant), Body dysmorphia; b Predictors: (Constant), Body dysmorpia, BMl; ' Predictors: (Constant), Body dysmorphia, BMl, Aggressiv.

Table 5. The results for the thee significant models in regression analysis.

\begin{tabular}{c|c|c|c|c|c|c}
\hline \multicolumn{2}{c|}{ Model } & Sum of Squares & df & Mean Square & F & Sig. \\
\hline \multirow{4}{*}{1} & Regression & 30047.143 & 1 & 30047.143 & 111.189 & $.000^{\mathrm{a}}$ \\
\cline { 2 - 8 } & Residual & 27293.769 & 101 & 270.235 & & \\
\cline { 2 - 8 } & Total & 57340.913 & 102 & & & \\
\hline \multirow{4}{*}{$\mathbf{2}$} & Regression & 32058.499 & 2 & 16029.250 & 63.401 & $.000^{\mathrm{b}}$ \\
\cline { 2 - 8 } & Residual & 25282.413 & 100 & 252.824 & & \\
\cline { 2 - 8 } & Total & 57340.913 & 102 & & & \\
\hline \multirow{4}{*}{3} & Regression & 33231.490 & 3 & 11077.163 & 45.486 & $.000^{c}$ \\
\cline { 2 - 8 } & Residual & 24109.422 & 99 & 243.530 & & \\
\cline { 2 - 8 } & Total & 57340.913 & 102 & & & \\
\hline
\end{tabular}

Predictors: (Constant), Body dysmorphia; b Predictors: (Constant), Body dysmorphia, BMl; ' Predictors: (Constant), Body dysmorphia, BMl, Aggressiveness; d. Dependent Variable: Exercise dependence.

\section{CONCLUSION}

Exercise may become physically and psychologically maladaptive if taken to extremes. The current study explored potential psychological, motivational, emotional and behavioral concomitants of bodybuilding dependence, with a particular focus on motives for weight training.
Table 6. Regression coefficients for the tree significant models of the regression analysis.

\begin{tabular}{|c|c|c|c|c|c|c|}
\hline & \multirow{2}{*}{ Model } & \multicolumn{2}{|c|}{$\begin{array}{l}\text { Unstandardized } \\
\text { Coefficients }\end{array}$} & \multirow{2}{*}{\begin{tabular}{|c}
$\begin{array}{c}\text { Standardized } \\
\text { Coefficients }\end{array}$ \\
Beta \\
\end{tabular}} & \multirow{2}{*}{$t$} & \multirow{2}{*}{ Sig. } \\
\hline & & B & $\begin{array}{l}\text { Std. } \\
\text { Error }\end{array}$ & & & \\
\hline \multirow{2}{*}{1} & (Constant) & 24.964 & 4.565 & & 5.468 & .000 \\
\hline & Body dysmorphia & .522 & .050 & .724 & 10.545 & .000 \\
\hline \multirow{3}{*}{2} & (Constant) & 64.240 & 14.608 & & 4.398 & .000 \\
\hline & Body dysmorphia & .506 & .048 & .701 & 10.488 & .000 \\
\hline & $\mathrm{BMI}$ & -1.517 & .538 & -.189 & -2.821 & .006 \\
\hline \multirow{4}{*}{3} & (Constant) & 56.395 & 14.776 & & 3.817 & .000 \\
\hline & Body dysmorphia & .412 & .064 & .571 & 6.455 & .000 \\
\hline & $\mathrm{BMI}$ & -1.482 & .528 & -.184 & -2.806 & .006 \\
\hline & Aggressiveness & .159 & .072 & .194 & 2.195 & .031 \\
\hline
\end{tabular}

Main findingsin this study can be interpreted in the following way: people who perceive their bodies as dismorphic, manifest lower level of self-esteem, in order to improve their physical appearance these people attend the gym. If we take into account other characteristics such asunfavorable BMI, aggressiveness, problems with the low and unmarried status then it is not surprising that line between healthy exercising and exercise dependence is crossed.Particularly important finding is that aggressiveness and exercise dependence are connected, especially as we found that exercise dependence is connected with problems with the law as a possible consequence of aggressiveness, as well as body dysmorphia.

Our research did not provide evidence for the possible influence of socio-demographic variables like: material status, number of brothers and sisters, level of education and completeness of their family on developing exercise dependence with those who practice in gyms. The same was with the potential influence of participants' health and medicament use.

All authors declare no potential conflict of interest related to this article.

AUTHORS' CONTRIBUTIONS: Each author made significant individual contributions to this manuscript. AN (0000-0003-3079-7180)*: contributed to the conception and design of the study, writing of the article, reviewing and carrying out the examination; ŽM (0000-0002-0902-9921)*: data analysis, writing and critical review of the article; VJ (0000-0001-6072-085X)*: writing the article, and final approval of the version of the manuscript to be published; BR (0000-0003-3841-3524)*: writing and revision, as well as all the intellectual content of the article. *ORCID (Open Researcher and Contributor ID).

\section{REFERENCES}

1. Lynch WJ, Peterson AB, Sanchez V, Abel J, Smith MA. Exercise as a novel treatment for drug addiction: a neurobiological and stage-dependent hypothesis.Neurosci. Biobehav Rev. 2013;37(8):1622-44.

2. Sarris J, O'Neil A, Coulson CE, Schweitzer I, Berk M. Lifestyle medicine for depression. BMC Psychiatry.2014;14(1):107.

3. Lichtenstein MB, Christiansen E, Elklit A, Bilenberg N, Støving RK. Exercise addiction: a study of eating disorder symptoms, quality of life, personality traits and attachment styles.Psychiatry Res. 2014;215(2):410-6.

4. Freimuth M, Moniz S, Kim SR. Clarifying exercise addiction: differential diagnosis, co-occurring disorders, and phases of addiction. Int J Environ Res Public Health. 2011;8(10):4069-81.

5. Carter RR, Johnson SM, Exline JJ, Post SG,Pagano ME. Addiction and generation me: narcissistic and prosocial behaviors of adolescents with substance dependency disorder in comparison to normative adolescents. Alcohol Treat Q. 2012;30(2):163-78.

6. Berczik K, Szabo A, Griffiths MD, Kurimay T, Kun B, Urban R, et al. Exercise addiction: symptoms, diagnosis, epidemiology, and etiology. Subst Use and Misuse. 2012;47(2):403-17.

7. Stapleton P, McIntyreT, Bannatyne A. Body image avoidance, body dissatisfaction, and eating pathology: is there a difference between male gym users and non-gym users? Am J Mens Health. 2016;10(2):100-9.

8. Bruno A, Quattrone D, Scimeca G, Cicciarelli C, Romeo VM, Pandolfo G, et al. Unraveling exercise addiction: the role of narcissism and self-esteem. J Addict. 2014;2014:987-841.

9. Hausenblas HA, Symons Downs D. Exercise dependence: a systematic review. Psychol Sport Exerc. 2002;3:89-123.

10. Cella S, lannaccone M, Cotrufo P. Muscle dysmorphia: a comparison between competitive bodybuilders and fitness practitioners. J Nutritional Therapeutics. 2012;1:12-8.
11. Lackovic-Grgin K, i saradnici. Zbirka psihologijskih skala i upitnika. Zadar: Filozofski Fakultet; 2002

12. Babic L, Kordic B. Samopuzdanje i stavovi zaposlenih prema edukaciji. Bijeljina: Naučni skup sa međunarodni učešćem Sinergija; 2009

13. Alinčić M. Osobine ličnosti i asertivnost kao prediktori samopoštovanja i socijalne anksioznosti. Primenjena Psihologija. 2013;6(2):139-54.

14.Zubić I, Todorović D, Mitić P. Emotional competence and aggression within students of sport and psysical education and students of electronic enneering. Resaarch in Kinesiology. 2013;41(1):69-75.

15. Isen JD, McGue MK, laconoWG. Aggressive-antisocial boys develop into physically strong young men.Psychol Sci. 2015;26(4):444-55.

16. Phillips AK, Wilhelm S, Koran LM, Didie ER, Fallon BA, Feusner J, et al. Body dysmorphic disorder: some key issues for DSM-V. Depresion and Anxiety. 2010;27:573-91.

17. Olivardia R, Pope Jr HG,Borowiecki III JJ, Cohane GH. Biceps and body image: the relationship between muscularity and self-esteem, depression, and eating disorder symptoms. Psychology of Men \& Masculinity. 2004;5(2):112-20

18. Blashill AJ, WilhelmS. Body image distortions, weight, and depression in adolescent boys: longitudinal trajectories into adulthood. Psychology MenMasc. 2014;15(4):445-51.

19. Hoffmeister K, Teige-Mocigemba S, Blechert J, Klauer KC,Tuschen-Caffier, B.Is implicit self-esteem linked to shape and weight concerns in restrained and unrestrained eaters? J Behav Ther Exp Psychiatry. 2010;41:31-8.

20. Fuchs T. The Phenomenology of shame, guilt and the body in body dysmorphic disorder and depression J Phenomenol Psychol. 2002;33(2):223-43. 